\title{
THE ROLE OF INTEREST RATES AND PROVINCIAL MONETARY AGGREGATE IN MAINTAINING INFLATION IN INDONESIA
}

\author{
Chandra Utama, Miryam B.L. Wijaya, and Charvin Lim
}

\begin{abstract}
Monetary policy may employ interest rate or money supply to derive the assigned national inflation target. In this manner, most studies investigate monetary policy effectiveness using national data. However, based on the idea that inflation is a regional phenomenon, the application of provincial data is more appropriate in explaining the relationship between monetary instrument and inflation. This study elaborates the impact of changes in provincial money supply, BI Rate (interest rates of central bank), and PUAB (money market interest rates) to regional inflation in Hybrid New Keynesian Phillips Curve (HNKPC) framework. This study employs Generalized Method of Moments (GMM) techniques on panel data of 32 provinces from 2005-III to 2013-III. The data is classified into 4 groups, which are Java-Bali (W1), Sumatera (W2), Kalimantan-Sulawesi (W3), and Papua-Maluku-Nusa Tenggara (W4). The estimation result shows that each monetary instrument has diverging effectiveness in different regions. Provincial monetary aggregate is only effective in Sumatera, while BI Rate can manage inflation in Sumatera and Kalimantan-Sulawesi. PUAB, on the other hand, is significantly affecting inflation in almost all Indonesian regions, except KalimantanSulawesi. We conclude that interest rate (BI rate and $P \cup A B$ ) is a more appropriate instrument, compared to provincial monetary aggregate, to control provincial inflation in Indonesia.
\end{abstract}

Keywords: Monetary policy, regional inflation, hybrid NKPC

JEL Classification: E31, E52, R19

1 Authors are researcher on Center for Economic Studies (CES) Parahyangan Catholic University. Chandra Utama (chandradst@unpar. ac.id); Miryam B. L. Wijaya (mlwijaya@unpar.ac.id); Charvin Lim (charvin.kusuma@unpar.ac.id).

Acknowledgement: The authors are grateful to participants of CES discussion sessions, the 2015 IRSA International Seminar in Denpasar, and the 2015 BEMP International Conference in Jakarta. They also especially thank BEMP anonymous referees for their comments and suggestions which improved this paper. All remaining errors are ours. Financial support from Parahyangan Catholic University, grant \# III/LPPM/2015-02/47-P is acknowledged. 


\section{INTRODUCTION}

Inflation has become the main concern in monetary authorities since it influences purchasing power and business climate, which in turn will determine macroeconomic variables such as national output and unemployment. Bank Indonesia (BI) has been granted an ultimate goal of achieving and maintaining the stability of rupiah toward the prices of goods and services, which are reflected in inflation (internal stability), and the exchange rate (external stability). In order to achieve the goal, BI implemented a monetary policy framework with inflation as its main target (Inflation Targeting Framework (ITF)) and free floating as its exchange rate system. In ITF inflation target is publicly announced to the public and designed in a forward looking manner, meaning that changes in monetary policy stance is done through an evaluation whether the development of inflation is still in line with the inflation target.

In the ITF, the inflation target, the monetary policy operational target, and the measurement of success are all engaged in national level indicator. However, investigation for national data is inadequate, since Indonesia has a considerably large territory with different economic structures and performances among its regions. The application of regional data in assessing monetary policy effectiveness and inflation behavior is thus imperative. This regional approach is important since, currently, the aggregate national inflation is dominated by only several regions in Indonesia. The inflation in Java is weighted for $64.5 \%$ of the national indicator. Moreover, Java and Sumatera (two out of many regions in Indonesia) represented $84.3 \%$ of the national inflation (Bank Indonesia, 2009). It suggests that non-Java territory, which has 28 provinces and is appreciably larger in term of area, only has $35.5 \%$ of national inflation weight. Further, all provinces outside Java and Sumatera are only weighted for $15.7 \%$ of the national inflation. If we explore further we can find that the weighting of Jakarta-Bogor-Depok-Tangerang-Bekasi (known as Jabodetabek), as the main business district in Indonesia, have covered $37.65 \%$ of national inflation. Hence, based on this condition, if the inflation target, monetary adjustment, and policy evaluation are based on national inflation, they will dominantly be determined only by the condition of Java-Sumatera or Java, or particularly, Jabodetabek.

The monetary stance in the ITF is reflected in the determination of BI Rate, which is expected to influence interest rates in money market, banking deposit, and loan market. The implementation of interest rate policy, including BI Rate and money market interest rates or Pasar Uang Antar Bank (PUAB O/N)2 , reflect an effort to achieve the targeted inflation using national inflation through a "nationally constructed" operational target. In consequence, considering the different weighting and idiosyncrasies of each region, questions arisen: Are the "nationally constructed" operational target (the interest rate instruments) effective for managing inflation in every region in Indonesia? Or are they only effective to manage inflation

2 This is the operational target of the interest rate. Depending on inflation expectation and several sets of variables, Bank Indonesia will set the policy rate (BI Rate) to influence the interbank money market rate or PUAB O/N, which will affect the deposit and the lending rate within the banking. We will refer the PUAB O/N as PUAB for the rest of this paper. 
in Java and Sumatera? Is it more appropriate to regulate the provincial money supply to directly influence inflation in each region? This research applies the framework of Hybrid New Keynesian Phillips Curve (NKPC) to learn whether BI Rate, PUAB, or money supply is the most effective instrument in managing regional inflation. We also identify the time lag of regional inflation responses toward these monetary instruments.

\section{THEORY}

\subsection{Controlling Inflation: Price or Quantity Based?}

In the early stage of monetary policy development, money supply was widely accepted as an instrument to maintain price stability. The rationale which advocates the relationship between monetary aggregate and inflation is explained by the quantity theory of money (QTM). The theory asserts that if monetary authority decides to change the amount of money supply in the economy, in the long run it will change the price level in the same proportion. This preposition suggests the effectiveness of using monetary aggregate as the operational target of monetary policy.

Support for this approach is overlaid by Fisher hypothesis which conjectured constant state of real interest rate. Asserting certain commensurate movement between expected inflation and nominal interest rate, the preposition implies no real economic effect would occur by changes in the nominal interest rate. Fisher Hypothesis claims that there is no apparent relationship between expected inflation and real interest rate ${ }^{3}$. Michell-Innes (2006) stated that important studies regarding the Fisher Hypothesis are performed by Mishkin (1995) which provide comprehensive explanation for the transmission mechanism of monetary policy using monetary aggregate.

In the recent development, however, monetary authority in various countries have justified the adoption of short-term interest rate as their operational target rather than monetary aggregate. Policy models started to set aside the relationship between money supply and inflation, and focus more on the relationship between interest rate and inflation. This phenomenon was reviewed by MacCallum and Nelson (2010) who have shown that most publications which contributed to monetary handbook are minimizing the role of monetary aggregate in the theory and analysis of monetary policy.

Many economists had performed studies in order to identify the relationship between interest rate and inflation, one of them was Brzoza-Brzezina (2002). Later publication by Woodford (2003), based on the idea from Wicksellian, discussed the process of real interest rate and natural rates of interest ${ }^{4}$ in influencing inflation.

3 See Lucas (1980), Fried and Howitt (1983).

4 The level of interest rate which would maintain stable price. 
According to Goto and Torous (2003), the aggressive policy of anti-inflation was pioneered by Taylor in 1995 who formulated the famously known Taylor Rule ${ }^{5}$. Taylor Rule explains that nominal short-term interest rate needs to move quicker than the expected inflation (move more than one-for-one) in order to maintain price stability. The monetary conduct, therefore, yield a positive relationship between inflation and real value of interest rate. This view becomes the cornerstone of ITF implementation (Handa, 2009).

The Taylor Rule contradicts Fisher Hypothesis which claimed the non-existent of more than one-for-one rule between inflation and interest rate. While Taylor Rule stated that changes in interest rate will determine the changes of inflation, Fisher Effect stated that it is money supply which cause the simultaneous changes between interest rate and inflation.

A view supporting the Fisher Hypothesis comes from Monnet and Weber (2001) who stated that, while the monetary authority is able to adjust the interest rate, it will only change the controllable instrument such as bank reserves. The changes in this instrument influences money supply and then money market reacts to it, reflected by the changes in the interest rate. The view of Monnet and Weber (2001) supports money supply as the key element which would determine the interest rate and inflation. Shresta et al. (2002) also contradict Taylor Rule by asserting a negative correlation between expected inflation and interest rate. Further, Handa (2009) also gives support to Fisher Hypothesis, arguing that in the long term, the relationship between money supply and interest rate is very high (with 0.7 or more as their correlation) indicating that changes in money supply will determine the changes in interest rate and in turn will influence inflation.

Moving to empirical aspect, there has been mixed results regarding the validity of Fisher Hypothesis. A study on developing country undertaken by Garcia (1993) in Brazil found that Fisher Hypothesis is occurring in the country. Other studies were conducted by Phylaktis and Blake (1993) and Carneiro et al. (2002) for Brazil, Mexico, and Argentina. While Phylaktis and Blake (1993) found that Fisher Effect is occurring in those three countries, Carneiro et al. (2002) only found the effect to be valid in Argentina and Brazil.

For the alternative instrument, the history of the United States monetary conduct provides evidence for the effectiveness of maintaining price stability through aggressive interest rate rule (Clarida et al., 2000). The pre-Volcker period (before 1979) with moderate monetary stance are found to be less stabilizing compared to Volcker-Greenspan period, which put forward an aggressive monetary conduct. In the earlier era, Federal Reserve typically alter nominal interest rate in a lesser extent than the increase in expected inflation, leading to a fall in the real interest rate. Contrarily, Volcker-Greenspan systematically raise real interest rate in dealing with increasing inflation expectation. The latter approach is found to provide an era of greater price stability.

5 See Taylor (1995). 


\subsection{Regional Inflation Variation and The Impact Of Monetary Policy on Regional Inflation}

Monetary policy is designed structurally and purposely for an ultimate national goal - price stability. Yet, the impact of monetary policy may differ among regions in a country. Differences may occur because of varying regional conditions, such as industrial competitiveness, financial structure, trading activities, and institutional environment. However, studies regarding the effectiveness of monetary policy are still commonly performed using national-level data. In this section, we review studies which exploits regional aspects in assessing monetary policy effectiveness.

Studies regarding the effectiveness of ITF in provincial level had been undertaken in China. Mehrotra et al. (2007) found that in 1978-2004 there is a variation of inflation among China provinces. They also found that there are 22 out of 29 provinces where forward looking inflation component is statistically significant in determining the actual inflation. In ITF, the significance of forward looking inflation component will increase the effectiveness of monetary policy.

Similar to China, Indonesia is a country with broad geographical territory and diverse social and economic condition. Ridhwan et al. (2011) shows that, while tight monetary policy might be conducive for the economy of Java, it may have a destructive effect on the economy of nonJava regions. This result indicates that one monetary conduct might bring about constructive effect on a region and a neutral or, even, destructive effect on the other.

Another research by Chaban and Voss (2012) found that there is inflation variation in 10 provinces in Canada. All of the provinces, aside from Alberta, indicated the existence of anchored inflation expectation which supported the effectiveness of ITF. They assert that the success measure of ITF can be exhibited by its capability to certainly determine the expected inflation to be strictly around the inflation target and that the deviation cannot be predicted. In provincial-level, we can question the deviation of provincial inflation to its national target. If there is a considerable gap between provincial and national deviation, the nationally constructed inflation target is not equally successful in each region.

\subsection{Hybrid NKPC model}

In this research, we estimate inflation using a theoretical framework developed by Gali and Gertler (1999) so called Hybrid NKPC model. According to Gali and Gertler, every firm adjust their prices in every periods with the fixed probability of $(1-\theta)$. There are two types of firm, $(1-\omega)$ are firms with forward-looking behavior as Calvo (1983) stated in his study while the rest, $\omega$, are firms with backward-looking behavior. Based on this condition, aggregate price can be constructed as equation (1). If the price set by forward looking firm is $p_{t}^{f}$ and backward looking firm is $p_{t}^{b}$, hence the new price is: 


$$
p_{t}^{*}=(1-\omega) p_{t}^{f}+\omega p_{t}^{b}
$$

Forward looking firms behave as Calvo's (1983) assertion, therefore $p_{t}^{f}$ can be derived as

$$
p_{t}^{f}=(1-\beta \theta) \sum_{k=0}^{\infty}(\beta \theta)^{k} E_{t}\left\{m c_{t+k}^{n}\right\}
$$

While $p_{t}^{b}$, equal to the average of adjusted price in the last period. The price can be denoted as

$$
p_{t}^{b}=\bar{p}_{t-1}^{*}+\pi_{t-1}
$$

Hence, the specification form of hybrid NKPC is

$$
\pi_{t}=\lambda m c_{t}+\gamma_{f} E_{t}\left\{\pi_{t+1}\right\}+\gamma_{b} \pi_{t-1}
$$

In empirical testing, equation (4) is estimated using non-linier instrumental variable (GMM) estimator. In their study, Gali and Gertler (1999) provided several strong findings regarding inflation behavior. First, the real marginal cost is statistically significant and is an important determinant of inflation (in this study we used output gap). Second, the behavior of forward looking is crucial because most of the firms have this kind of behavior. $T$; they found that $60-80 \%$ of the firms are forward looking behavior. Third, the behavior of backward looking is statistically significant. Therefore, even though forward looking behavior is plausible, pure forward looking model cannot be accepted. Last but not the least, it takes time for prices to change (sticky price).

\section{METHODOLOGY}

In this research, we use quarterly panel data of 32 provinces in Indonesia covering the period of 2005-III to 2013-III. Most of the data are obtained in quarterly report of Perkembangan Perekonomian Daerah (Pekda) and Kajian Ekonomi Regional (KER) which are published by Kantor Bank Indonesia (K.BI) in provinces. Table 1 explains the definition of variable which are observed in this study. 


\begin{tabular}{|c|c|c|c|}
\hline Variable & Sign & Measure & Explanation \\
\hline Inflation & $\pi_{i, t}$ & Percentage & Year-on-year inflation \\
\hline Actual output & $y_{i t}^{a}$ & Trillion rupiah & Real regional output (base: year 2000) \\
\hline Potential output & $y_{i t}^{*}$ & Trillion rupiah & Estimated using Hodric-Prescott Filter \\
\hline Output gap & $y_{i t}$ & Percentage & $y_{i t}=\frac{\left(y_{i t}^{a}-y_{i t}^{*}\right)}{y_{i t}^{*}} \times 100 \%$ \\
\hline $\begin{array}{l}\text { Changes in real } \\
\text { money supply }\end{array}$ & $m_{i t}$ & Trillion rupiah & $\begin{array}{l}m_{i t} \text { is the changes in real currency money }\left(\Delta K_{i t}\right) \text { added by real demand } \\
\text { depositn }\left(\Delta G_{i t}\right) . \Delta K_{i t} \text { is the net flow of currency in regional office central } \\
\text { bank. } \Delta G_{i t} \text { is the changes in demand deposit in each province's banking. }\end{array}$ \\
\hline BI Rate & $r 1_{t}$ & Percentage & Central bank interest rate; national data \\
\hline PUAB & $12_{t}$ & Percentage & Money market interest rate; national data \\
\hline
\end{tabular}

We use year-on-year inflation to compare the development of inflation among provinces based on inflation in the previous year. Inflation is calculated using provincial consumer price index (CPI). Even though the original data of CPI is the general price in city, Pekda and KER have provided provincial CPI data. For Papua and Papua Barat, including Banten and Jakarta, the CPI data or inflation is compounded in a particular proportion based on Pekda and KER.

For economic output indicator, we use real RGDP (Regional Gross Domestic Product) with year 2000 as its base year. Hodrick-Prescott Filter (HP Filter) is applied in order to obtain potential output, $y_{i t}^{*}$, based on the real PDRB data. The output gap, $y_{i t}$, is the reduction of actual output to potential output, divided by potential output, multiplied by $100 \%$.

Because of the unavailability of provincial money supply data, we use the net flow of currency in provincial central bank branch offices (Kantor Bank Indonesia) as proxy of currency changes. If the outflow is greater than inflow (net outflow), there is an increase of currency supply in the region, vice versa. We also use demand deposit changes in commercial bank (conventional and Islamic banking) as the proxy of provincial demand deposit changes. The sum of currency changes and demand deposit changes is utilized as the changes of money supply in each province.

For interest rate instruments, we use $B I$ Rate, $r 1_{t^{\prime}}$ and PUAB, $r 2_{t}$. These variables are commonly used as the national monetary policy references. In contrast to $\mathrm{m}_{\mathrm{it} \text {, }}$ which is a provincial level data, $r 1_{t}$ and $r 2_{t}$ is a national-level data therefore the value for these variables are identical for each period in every provinces. $^{6}$

6 Depending on the covariance structure of the equation block representing the panel data, using SUR is plausible when the set of exogenous variables are uniform across equations. However, in this paper we simply use one equation while the possible correlation across provinces may be adjusted during the estimation (i.e. white cross section). We thank to the anonymous reviewer of this journal for a good discussion and suggestion on this issue. 
To analyze the impact of policy variable toward provincial inflation we employ and modify Hybrid NKC framework developed by Gali and Gertler (1999):

$$
\pi_{i t}=\gamma_{b} \pi_{i, t-1}+\gamma_{f} \pi_{i, t+1}+\alpha_{\lambda} y_{i t}+\varepsilon_{i t}
$$

We add policy variable, $S_{i t}$ on the basic form of Hybrid NKPC, hence equation (5) become:

$$
\pi_{i t}=\gamma_{b} \pi_{i, t-1}+\gamma_{f} \pi_{i, t+1}+\alpha_{\lambda} y_{i t}+\delta_{m} S_{i t}+\varepsilon_{i t}
$$

where $S_{i t}$ may contain $m_{i t^{\prime}} \mathrm{r}_{t^{\prime}}$ or $\mathrm{r}_{\mathrm{t}}$. Adapting Gali and Gertler (1999), we applied Generalized Method of Moments (GMM) as the estimation technique and employ $\varpi_{i, t-2}$ and $\varpi_{i, t-4}$ as the instrument variable. Estimating equation (6), we can identify the backward looking and forward looking behavior impacts by referring to $\gamma_{b}$ and $\gamma_{f}$. We can also analyze the influence of output gap, $y_{i t^{\prime}}$ on inflation. In order to assess the impact of policy variable on inflation, we employ to $\delta_{m}$.

Equation (6) is also used for the estimation of policies impact with, taking into account, regional aspect consideration. Since it is most likely that monetary policies need time lag in order to take effect on the economy, we try to determine the best time lag by repeating the estimation of equation (6) using different time lags. The criteria used in determining the best time lag are the conformity of the impact direction with the theory and policy objective, which are positive for $r_{t}$ and $r_{t^{\prime}}$ and negative for $m_{i t^{\prime}}$ and the swiftness of effect. ${ }^{7}$ Based on equation (6) we construct an inflation model which takes into account the influence-differences among regions

$$
\begin{gathered}
\pi_{i t}=\gamma_{b} \pi_{i, t-1}+\gamma_{f} \pi_{i, t+1}+\alpha_{\lambda} y_{i t}+\delta_{m 1} S_{i t}+\delta_{m 2} 2 S_{i t} d 2_{i t}+ \\
\delta_{m 3} S_{i t} d 3_{i t}+\delta_{m 4} S_{i t} d 4_{i t}+\varepsilon_{i t}
\end{gathered}
$$

where $d_{2}, d_{3}$, and $d_{4}$, are dummy variables for Sumatera (W2), Kalimantan-Sulawesi (W3), and Papua-Maluku-Nusa Tenggara (W4). Furthermore, $\mathrm{d}_{1}$, which represents Jawa-Bali region (W1), is not included in the model because of its role as the comparator and control dummy. Table 2 explains the classification of regions and its provinces.

7 The choice of exogenous policy lag impact is different from the autoregression process where the lag of the variable in question is the endogenous one; we use AIC or Scwartz on the letter. 


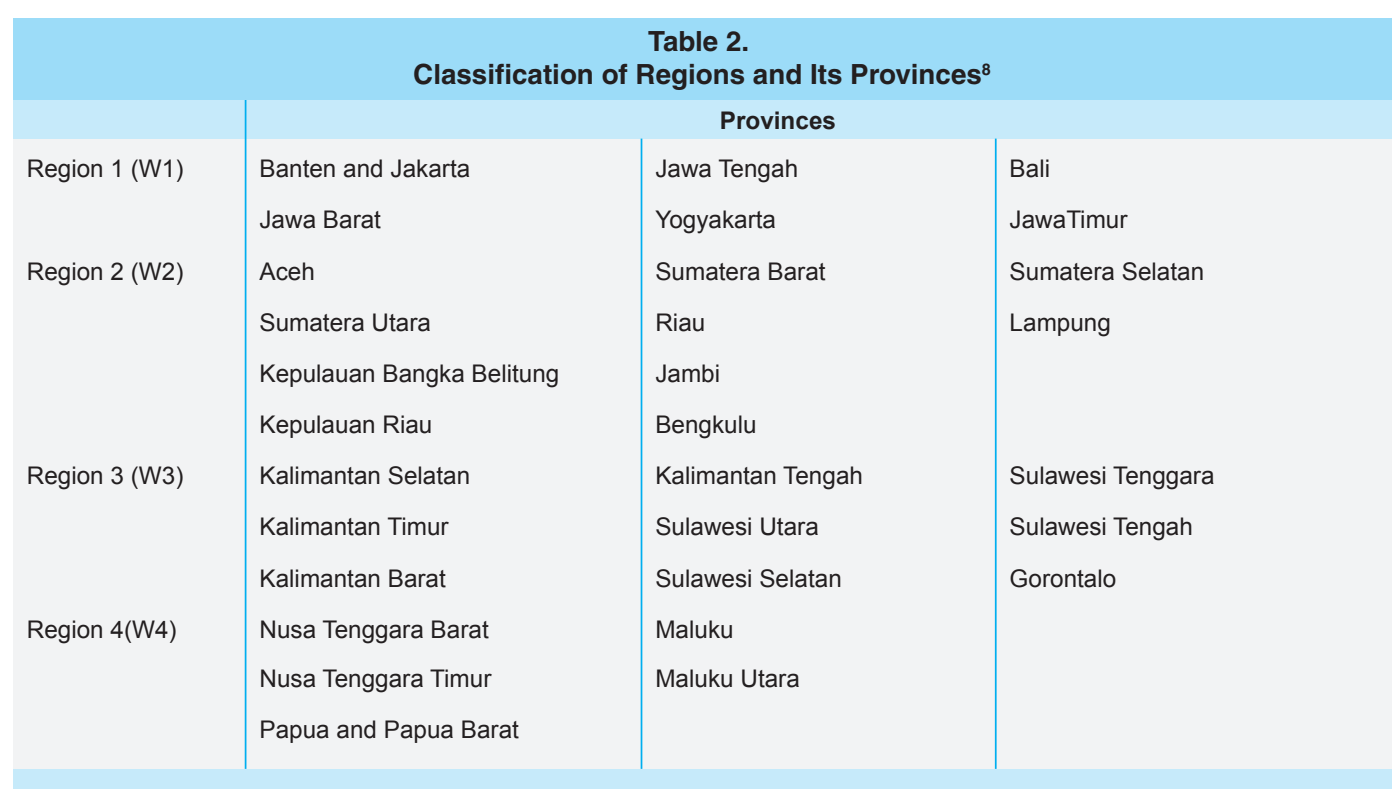

Based on equation (7), the impact of monetary instruments on inflation in Region 1, 2, 3 , and 4 are consecutively $\delta_{m 1^{\prime}}\left(\delta_{m 1}+\delta_{m 2}\right),\left(\delta_{m 1}+\delta_{m 3}\right)$, and $\left(\delta_{m 1}+\delta_{m 4}\right)$. In order to identify the significance of each policy impact coefficient, we run the Wald test. Using equation (7) we can identify the coefficient differences between Jawa-Bali region (W1) and the other regions by learning coefficient $\delta_{m 2^{\prime}} \delta_{m 3^{\prime}}$ and $\delta_{m 4}$. However, we cannot identify the coefficient differences among regions except of using W1 as the comparator. For that purpose, we use Wald test in comparing the coefficient difference of each regions.

\section{RESULT AND ANALYSIS}

\subsection{Provincial Inflation Model}

Table 3 displays the estimation result of three equations using Hybrid NKPC framework. Each equation has different policy variable, which are money supply, policy rate (BI Rate), and interbank money rate (PUAB). The results indicate the existence of backward looking and forward looking behavior in the determination of Indonesian inflation. Forward looking tends to be more dominant, suggested by its significance and coefficient level. In concordance with the theoretical prediction, output gap has also a significant role in the construction of inflation.

8 Jakarta and Banten is reported in the same account, and so, in this research, they are combined for all period. So do Papua and Papua Barat. Moreover, although Indonesia has 34 provinces in 2013, Kalimantan Utara and Sulawesi Barat are not included as observations because the data for those provinces are not available in all observation period (Sulawesi Barat was just established in 5th October 2004, while Kalimantan Utara was established in 25th October 2012). Table 2 shows the provinces included as observations in this research. 


\begin{tabular}{|c|c|c|c|c|c|c|}
\hline \multicolumn{7}{|c|}{$\begin{array}{c}\text { Table } 3 . \\
\text { Estimation Result of Provincial Inflation Model }\end{array}$} \\
\hline & \multicolumn{2}{|c|}{$\pi_{i t}$} & \multicolumn{2}{|c|}{$\pi_{i t}$} & \multicolumn{2}{|c|}{$\pi_{i t}$} \\
\hline & Coef. & Prob. & Coef. & Prob. & Coef. & Prob. \\
\hline$\pi_{i, t-1}$ & 0.4429 & 0.0000 & 0.0887 & 0.0000 & 0.3252 & 0.0000 \\
\hline$\pi_{i, t+1}$ & 0.6330 & 0.0000 & 0.2992 & 0.0000 & 0.6579 & 0.0000 \\
\hline$y_{i t}$ & 0.2020 & 0.0000 & 0.0364 & 0.0011 & 0.1063 & 0.0000 \\
\hline$S_{i t}=m_{i t}$ & $-1.4 \mathrm{E}-07$ & 0.0001 & & & & \\
\hline$S_{i t}=r 1_{i t}$ & & & 1.5515 & 0.0000 & & \\
\hline$S_{i t}=r 2_{i t}$ & & & & & 0.4736 & 0.0000 \\
\hline$N$ & & 900 & & 900 & & 900 \\
\hline Instrument rank & & 30 & & 30 & & 30.0000 \\
\hline J-stat. & & 29.96381 & & 29.85828 & & 29.6851 \\
\hline prob. & & 0.269113 & & 0.273524 & & 0.2809 \\
\hline
\end{tabular}

On the role of money supply, BI Rate, and PUAB in determining the level of inflation, Table 3 shows significant contradictive directions. The result suggests that an increase in money supply would lower inflation, while an increase in interest rate raises inflation. We suspect this peculiar result is in accordance with Friedman's proposition on short-run monetary ineffectiveness. According to Friedman, monetary instruments need time in order to effectively affect the objective variable. Friedman argued that the long period of lag required by the economy to respond to monetary policy produce peculiar short-term relationship between monetary instrument and inflation. Batini and Nelson (2001) further confirm Friedman's proposition of monetary policy ineffectiveness in the short-run using data from 1953 to 2001 in the United States and United Kingdom.

Since the application of policy variables without time lag yield a conflictive result and that monetary policy need time to affect the economy, we try to re-estimate the model by adding time lag for the policy variables until we found each policy variable to have significant and corresponding effect to the policy objective. The lag would then demonstrate the nearest time in which monetary policy would produce the intended effect on inflation. The result is estimated and presented in Table 4.

In concordance with the earlier result, the estimations show that backward looking and forward looking behavior have positive significant effects on inflation, with forward looking having greater influence. In accordance with the theory, output gap is also found to have a positive effect on inflation. By adding time lag worth one quarter, the estimation results of 
monetary policies influence have changed. Money supply is shown to have insignificant effect on inflation, while BI Rate a contradictive effect. However, the estimation result on PUAB has shown the expected result. PUAB has a negative significant effect on the future inflation, with a time lag of one quarter. It suggests that, different with the other two policies, PUAB will become an effective policy in three months after its implementation. The value of J-statistic probability professes that there is no over-identification in the model.

\begin{tabular}{|c|c|c|c|c|c|c|}
\hline \multicolumn{7}{|c|}{$\begin{array}{l}\text { Table } 4 . \\
\text { Estimation Result of Provincial Inflation Model with1 Period Time Lag }\end{array}$} \\
\hline & \multicolumn{2}{|c|}{$\pi_{i t}$} & \multicolumn{2}{|c|}{$\pi_{i t}$} & \multicolumn{2}{|c|}{$\pi_{i t}$} \\
\hline & Coef. & Prob. & Coef. & Prob. & Coef. & Prob. \\
\hline$\pi_{i, t-1}$ & 0.444342 & 0.0000 & 0.202718 & 0.0000 & 0.468151 & 0.0000 \\
\hline$\pi_{i, t+1}$ & 0.636456 & 0.0000 & 0.615281 & 0.0000 & 0.618738 & 0.0000 \\
\hline$y_{i t}$ & 0.158972 & 0.0000 & 0.165596 & 0.0000 & 0.155991 & 0.0000 \\
\hline$S_{i t}=m_{i, t-1}$ & $-4.9 \mathrm{E}-09$ & 0.7151 & & & & \\
\hline$S_{i t}=r 1_{i, t-1}$ & & & 0.683177 & 0.0000 & & \\
\hline$S_{i t}=r 2_{i, t-1}$ & & & & & -0.07558 & 0.0000 \\
\hline$N$ & & 900 & & 900 & & 900 \\
\hline Instrument rank & & 30 & & 30 & & 30 \\
\hline J-stat. & & 29.8360 & & 29.7515 & & 29.8454 \\
\hline prob. & & 0.2745 & & 0.2780 & & 0.2741 \\
\hline
\end{tabular}

Table 5.

Estimation Result of Provincial Inflation using 2 and 3 Periods of Time Lag

\begin{tabular}{|c|c|c|c|c|c|c|c|c|}
\hline & \multicolumn{2}{|c|}{$\pi_{i t}$} & \multicolumn{2}{|c|}{$\pi_{i t}$} & \multicolumn{2}{|c|}{$\pi_{i t}$} & \multicolumn{2}{|c|}{$\pi_{i t}$} \\
\hline & Coef. & Prob. & Coef. & Prob. & Coef. & Prob. & Coef. & Prob. \\
\hline$\pi_{i, t-1}$ & 0.5094 & 0.0000 & 0.5392 & 0.0000 & 0.4903 & 0.0000 & 0.5669 & 0.0000 \\
\hline$\pi_{i, t+1}$ & 0.4993 & 0.0000 & 0.5385 & 0.0000 & 0.5017 & 0.0000 & 0.5163 & 0.0000 \\
\hline$y_{i t}$ & -0.0582 & 0.0000 & -0.0308 & 0.0369 & -0.0036 & 0.6988 & -0.0322 & 0.0063 \\
\hline$S_{i t}=m_{i, t-2}$ & $-2 E-07$ & 0.0000 & & & & & & \\
\hline$S_{i t}=m_{i, t-3}$ & & & 2.1E-7 & 0.0000 & & & & \\
\hline$S_{i t}=r 1_{i, t-2}$ & & & & & 0.0616 & 0.0000 & & \\
\hline$S_{i t}=r 1_{i, t-3}$ & & & & & & & 0.12075 & 0.0000 \\
\hline $\mathrm{N}$ & & 870 & & 840 & & 870 & & 840 \\
\hline Instrument rank & & 30 & & 30 & & 30 & & \\
\hline J-stat. & & 29.5054 & & 29.6032 & & 29.9087 & & 29.4934 \\
\hline prob. & & 0.2886 & & 0.2844 & & 0.2714 & & 0.2891 \\
\hline
\end{tabular}


We applied two quarter and three quarter periods of time lag in order to find the best time lag for BI Rate and money supply. All of the estimation results indicate that inflation level in Indonesia is significantly affected by backward looking and forward looking behavior. In contrast with the earlier results, these estimation suggest that backward looking behavior has a greater impact on inflation, meaning that the economy take into account past inflation more considerably than expected future inflation in constructing their expected inflation. In Table 5, we show that money supply and BI Rate need 3 quarters to effectively influence the inflation.

\subsection{Inflation Model with Regional Consideration}

In order to identify which monetary policy is better in maintaining regional inflation, we estimate each monetary policy's impact on each region. We started by assessing monetary aggregate, followed by BI Rate and PUAB sequentially. In order to identify differences in each region's response, we use dummy variable on monetary policy. Wald test is executed in order to evaluate the significance of monetary policy in each region and to diagnose if the policy effect is different.

Table 6 shows the estimation result of Hybrid NKPC model with regional consideration and monetary aggregate as the policy variable. $\mathrm{W} 1$ is used as the base comparator in this equation. The estimation result suggest that forward looking and backward looking behavior have significant roles in determining future inflation, with forward looking being a slightly greater determinant. Output gap is found to have no significant effect in determining inflation.

\begin{tabular}{|c|c|c|}
\hline \multicolumn{3}{|c|}{$\begin{array}{l}\text { Table } 6 . \\
\text { Estimation Result with Monetary Aggregate and Regional Response }\end{array}$} \\
\hline & \multicolumn{2}{|c|}{ 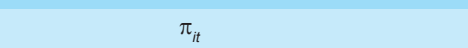 } \\
\hline & Coef. & Prob. \\
\hline$\pi_{i, t-1}$ & 0.5200 & 0.0000 \\
\hline$\pi_{i, t+1}$ & 0.5515 & 0.0000 \\
\hline$y_{i t}$ & 0.0142 & 0.5505 \\
\hline$m_{i, t-3}$ & $9.02 \mathrm{E}-08$ & 0.1444 \\
\hline$m_{i, t-3} d 2_{i, t}$ & 1.43E-06 & 0.0000 \\
\hline$m_{i, t-3} d 3_{i, t}$ & $-3.8 E-07$ & 0.1934 \\
\hline$m_{i, t-3} d 4_{i, t}$ & $-1.1 \mathrm{E}-06$ & 0.0029 \\
\hline $\mathrm{N}$ & 840 & \\
\hline Instrument rank & 30 & \\
\hline J-statistic & 29.32421 & \\
\hline Prob(J-statistic) & 0.1698 & \\
\hline
\end{tabular}


Table 7 displays the effect of monetary aggregate on each region's inflation. The Wald Test result shows that money supply is only significantly affecting the inflation of W2 (Sumatera) and W4 (Papua-Maluku-Nusa Tenggara) regions. While it has a positive effect on W2's inflation, it turns out to have negative effect on W4's. It suggests that employing monetary aggregate as the monetary instrument will only be effective for managing inflation in W2 region.

\begin{tabular}{|c|c|c|c|c|}
\hline \multicolumn{5}{|c|}{$\begin{array}{c}\text { Table } 7 . \\
\text { Wald Test: Effect of Monetary Aggregate on Each Region's Inflation }\end{array}$} \\
\hline & Jawa-Bali & Sumatera & $\begin{array}{l}\text { Kalimantan - } \\
\text { Sulawesi }\end{array}$ & $\begin{array}{l}\text { Papua - Maluku - } \\
\text { Nusa - Tenggara }\end{array}$ \\
\hline Coef. & $9.02 \mathrm{E}-08$ & 1.52E-06 & $-2.87 \mathrm{E}-07$ & $-1.00 \mathrm{E}-06$ \\
\hline F - statistic & 2.1345 & 76.9455 & 1.0900 & 8.4129 \\
\hline Prob. & 0.1444 & 0.0000 & 0.2968 & 0.0038 \\
\hline
\end{tabular}

\begin{tabular}{|c|c|c|c|c|c|}
\hline \multicolumn{6}{|c|}{$\begin{array}{c}\text { Table } 8 . \\
\text { Wald Test: Monetary Aggregate's Impact Differences Between Regions }\end{array}$} \\
\hline & & Jawa-Bali & Sumatera & $\begin{array}{l}\text { Kalimantan - } \\
\text { Sulawesi }\end{array}$ & $\begin{array}{c}\text { Papua - Maluku - } \\
\text { Nusa Tenggara }\end{array}$ \\
\hline Jawa-Bali & $\begin{array}{l}\text { F-Stat } \\
\text { (Prob.) }\end{array}$ & & $\begin{array}{r}75.3142 \\
(0.0000)\end{array}$ & $\begin{array}{r}1.6946 \\
(0.1934)\end{array}$ & $\begin{array}{r}8.9352 \\
(0.0029)\end{array}$ \\
\hline Sumatra & & $\begin{array}{r}75.3142 \\
(0.0000)\end{array}$ & & $\begin{array}{l}30.1851 \\
(0.0000)\end{array}$ & $\begin{array}{l}40.8928 \\
(0.0000)\end{array}$ \\
\hline Kal-Sul & & $\begin{array}{r}1.6946 \\
(0.1934)\end{array}$ & $\begin{array}{l}30.1851 \\
(0.0000)\end{array}$ & & $\begin{array}{r}4.3247 \\
(0.0379)\end{array}$ \\
\hline Pap-Mal_Nusa & & $\begin{array}{r}8.9352 \\
(0.0029)\end{array}$ & $\begin{array}{c}40.8928 \\
(0.0000)\end{array}$ & $\begin{array}{r}4.3247 \\
(0.0379)\end{array}$ & \\
\hline
\end{tabular}

Displayed by the estimation result in table 8, we found that money supply has no different impact on inflation in W1 and W3. The policy impact is especially unique in W2 and W4, where it is shown that there is no indifferent effect on other regions. 


\begin{tabular}{|c|c|c|}
\hline \multicolumn{3}{|c|}{$\begin{array}{c}\text { Table } 9 . \\
\text { Estimation Result with BI Rate and Regional Response }\end{array}$} \\
\hline & \multicolumn{2}{|c|}{$\pi_{i t}$} \\
\hline & Coef. & Prob. \\
\hline$\pi_{i, t-1}$ & 0.5740 & 0.0000 \\
\hline$\pi_{i, t+1}$ & 0.5094 & 0.0000 \\
\hline yit & -0.0463 & 0.0112 \\
\hline$r 1_{i, t-3}$ & 1.3058 & 0.1258 \\
\hline $\mathrm{r} 1_{i, t-3} \mathrm{~d} 2_{i, t}$ & -1.6213 & 0.0396 \\
\hline $\mathrm{r} 1_{\mathrm{i},-\mathrm{t}-3} \mathrm{~d} 3_{\mathrm{i}, \mathrm{t}}$ & -2.1693 & 0.0722 \\
\hline$r 1_{i, t-3} d 4_{i, t}$ & -1.4775 & 0.1761 \\
\hline $\mathrm{N}$ & 840 & \\
\hline Instrument rank & 30 & \\
\hline J-statistic & 28.9268 & \\
\hline Prob. (J-statistic) & 0.1827 & \\
\hline
\end{tabular}

Moving to BI Rate policy, table 9 displays the estimation result of Hybrid NKPC model with $\mathrm{BI}$ Rate as the shock variable. Different from the previous estimation, while backward looking and forward looking behavior still significantly affecting inflation, it is found that backward looking behavior has a slightly greater role in determining inflation. Contradicting the theory, we also found that an increase in output gap will lower inflation level.

Depicted in table 10, we found that BI Rate as a monetary instrument is only significantly affecting W2 region (Sumatera). Furthermore, Table 11 suggests that BI Rate has indifferent effect on W1 and W4. It is also found that W2 has the same responses as W3 and W4 on $\mathrm{BI}$ Rate changes. The impact of BI Rate on W3's inflation is also indifference to W4's. While it indicates that BI Rate may be a better and fairer policy in managing regional inflation, the result in table 11 suggest that $\mathrm{BI}$ Rate is only effective to be implemented in Sumatera regions.

\begin{tabular}{|c|c|c|c|c|}
\hline \multicolumn{5}{|c|}{$\begin{array}{l}\text { Table } 10 . \\
\text { WaldTest: Effect of BI Rate on Each Region's Inflation }\end{array}$} \\
\hline & Jawa-Bali & Sumatera & $\begin{array}{l}\text { Kalimantan- } \\
\text { Sulawesi }\end{array}$ & $\begin{array}{l}\text { Papua-Maluku- } \\
\text { Nusa Tenggara }\end{array}$ \\
\hline & (W1) & (W2) & (W3) & (W4) \\
\hline Coef. & 1.3058 & -0.3155 & -0.8635 & -0.1717 \\
\hline F-statistic & 2.3485 & 3.8237 & 4.4681 & 0.1852 \\
\hline Prob. & 0.1258 & 0.0509 & 0.0348 & 0.6671 \\
\hline
\end{tabular}




\begin{tabular}{|c|c|c|c|c|c|}
\hline \multicolumn{6}{|c|}{$\begin{array}{c}\text { Table } 11 . \\
\text { Wald Test: Diagnosis of BI Rate's Impact Differences between Regions }\end{array}$} \\
\hline & & Jawa-Bali & Sumatera & $\begin{array}{l}\text { Kalimantan- } \\
\text { Sulawesi }\end{array}$ & $\begin{array}{l}\text { Papua-Maluku- } \\
\text { Nusa Tenggara }\end{array}$ \\
\hline & & (W1) & (W2) & (W3) & (W4) \\
\hline \multirow[t]{2}{*}{ Jawa-Bali } & F Stat. & & 4.2467 & 3.2403 & 1.8336 \\
\hline & Prob. & & 0.0396 & 0.0722 & 0.1761 \\
\hline \multirow[t]{2}{*}{ Sumatra } & & 4.2467 & & 1.1297 & 0.0741 \\
\hline & & 0.0396 & & 0.2882 & 0.7855 \\
\hline \multirow[t]{2}{*}{ Kal-Sul } & & 3.2403 & 1.1297 & & 2.0217 \\
\hline & & 0.0722 & 0.2882 & & 0.1554 \\
\hline \multirow[t]{2}{*}{ Pap-Mal_Nusa } & & 1.8336 & 0.0741 & 2.0217 & \\
\hline & & 0.1761 & 0.7855 & 0.1554 & \\
\hline
\end{tabular}

The other alternative for monetary policy operational target is PUAB. Table 12 shows the estimation result of Hybrid NKPC model with PUAB as the shock variable. In this estimation result, we found that backward looking and forward looking behavior are significant in determining the level of inflation. We found forward looking behavior to be a greater determinant of inflation. It indicates that the expected future inflation has a bigger role in determining inflation than the inflation track records. In this equation result, we also found that the output gap impact on inflation is in line with theory.

\begin{tabular}{|c|c|c|}
\hline \multicolumn{3}{|c|}{$\begin{array}{l}\text { Table } 12 . \\
\text { Inflation Model with PUAB and Regional Response }\end{array}$} \\
\hline & \multicolumn{2}{|c|}{$\pi_{i t}$} \\
\hline & Coef. & Prob. \\
\hline$\pi_{i, t-1}$ & 0.4697 & 0.0000 \\
\hline$\pi_{i, t+1}$ & 0.6145 & 0.0000 \\
\hline$y_{i t}$ & 0.1463 & 0.0000 \\
\hline$r 2_{i, t-1}$ & -0.8723 & 0.0110 \\
\hline$r 2_{i, t-1} d 2_{i, t}$ & 0.6892 & 0.0555 \\
\hline$r 2_{i, t-1} d 3_{i, t}$ & 1.6945 & 0.0025 \\
\hline$r 2_{i, t-1} \mathrm{~d} 4_{i, t}$ & 0.2270 & 0.3969 \\
\hline $\mathrm{N}$ & 900 & \\
\hline Instrument rank & 30 & \\
\hline J-statistic & 29.3568 & \\
\hline Prob(J-statistic) & 0.1688 & \\
\hline
\end{tabular}


Table 13 presents the impact of PUAB on each observed region's inflation. We found that PUAB stands as the best monetary instruments compared to the two others in this study. PUAB has significant and in-line-with-objective effect on W1 (Jawa-Bali), W2 (Kalimantan-Sulawesi) and W4 (Papua-Maluku-Nusa Tenggara) regions. Still to be put in our concern, PUAB has a positive effect on W3 region (Kalimantan-Sulawesi) which contradict the policy objective.

\begin{tabular}{|c|c|c|c|c|}
\hline \multicolumn{5}{|c|}{$\begin{array}{c}\text { Table } 13 . \\
\text { Wald Test: Effect of PUAB on Each Region's Inflation }\end{array}$} \\
\hline & Jawa-Bali & Sumatera & $\begin{array}{l}\text { Kalimantan- } \\
\text { Sulawesi }\end{array}$ & $\begin{array}{l}\text { Papua-Maluku- } \\
\text { Nusa Tenggara }\end{array}$ \\
\hline & (W1) & (W2) & (W3) & (W4) \\
\hline Coef. & -0.8723 & -0.1830 & 0.8222 & -0.6453 \\
\hline F-statistic & 6.4851 & 11.4296 & 8.3421 & 4.7564 \\
\hline Prob. & 0.0110 & 0.0008 & 0.0040 & 0.0295 \\
\hline
\end{tabular}

Diagnosing the impact differences of PUAB between each region, we found that W1, W2, and W3 are having indifferent response toward the changes of PUAB (see table 14). On the other hand, we found that the impact of PUAB on inflation in W4 is only indifferent with its impact on W3. Considering the result, we assert that PUAB is a fair monetary instrument in controlling inflation level across regions in Indonesia.

\begin{tabular}{|c|c|c|c|c|c|}
\hline \multicolumn{6}{|c|}{$\begin{array}{c}\text { Table } 14 . \\
\text { Wald Test: Diagnosis of PUAB'S Impact Differences between Regions }\end{array}$} \\
\hline & & Jawa Bali & Sumatra & Kal-Sul & Pap-Mal-Nusa \\
\hline \multirow[t]{2}{*}{ Jawa-Bali } & F-Stat & & 3.6769 & 9.2163 & 0.7184 \\
\hline & Prob. & & 0.0555 & 0.0025 & 0.3969 \\
\hline \multirow[t]{2}{*}{ Sumatra } & & 3.6769 & & 12.8614 & 1.9798 \\
\hline & & 0.0555 & & 0.0004 & 0.1598 \\
\hline \multirow[t]{2}{*}{ Kal-Sul } & & 9.2163 & 12.8614 & & 7.0423 \\
\hline & & 0.0025 & 0.0004 & & 0.0081 \\
\hline \multirow[t]{2}{*}{ Pap-Mal_Nusa } & & 0.7184 & 1.9798 & 7.0423 & \\
\hline & & & 0.1598 & 0.0081 & \\
\hline
\end{tabular}




\section{CONCLUSION}

Designing an effective and reliable monetary policy is necessary to ensure national price stability. To achieve the desired level of inflation, monetary authority can employ quantity-based approach, which make use of monetary aggregate as its instrument, or price-based approach, which exploit interest rate. The utilization of interest rate as the monetary operational target may have its own advantages in directing national inflation, but then again interest rate is a one-for-all 'nationally-designed' instrument. Different from interest rate, money supply can be regulated in regional level, accommodating each region's economic needs. Since inflation is a regional phenomenon, a detailed assessment of each region's idiosyncrasy is a necessity. If authorities are concerned about the inflationary gap among regions, they need policy instrument(s) which is or are capable of managing regional inflation evenly. Through this study, we found that each region in Indonesia have different responses on monetary policy instruments.

Using Hybrid NKPC model, we found that backward looking and forward looking behavior have significant roles in determining inflation in Indonesia. Further, our finding supports Gali and Gertler (1999) in asserting forward looking behavior to have greater influence than backward looking. It suggests the importance and effectiveness of inflation targeting framework in directing societies' expectation regarding future inflation. Conforming macroeconomics theory, output gap is also found to have a positive impact on inflation.

Through regional analysis, we found that both monetary instruments (money supply and interest rate) are incapable of influencing inflation in the short run. Monetary policy needs time to effectively influence regional inflation. Our analysis suggests that PUAB instrument needs the least time lag to yield desirable influence on inflation. PUAB needs 1 quarter to effectively influence inflation while money supply and BI Rate needs 3 quarters. Furthermore, the estimation of PUAB alone delivers consistent backward and forward looking and output gap influence to regional inflation.

Taking into account regional aspect in the model, we found that money supply has a significant impact on inflation in Sumatera (W2) and Papua-Maluku-Nusa Tenggara (W4). This instrument, however, is only effective in Sumatera region, since the estimation result suggests that it would have conflicting effect in Papua-Maluku-Nusa Tenggara.

Moving to the second instrument, we found that BI Rate is an effective instrument in controlling the inflation in Sumatera (W2) and Kalimantan-Sulawesi (W3). In addition, through Wald test we found indifferent impact of BI Rate to inflation in these regions.

Lastly, we found that PUAB is the most favourable instrument in controlling inflation in Indonesia. Based on the estimation result, we found that PUAB is potent to manage inflation in most of the observed regions, including Java-Bali (W1), Sumatera (W2), and Papua-MalukuNusa Tenggara (W4). In those regions, the influence of PUAB to inflation is in concordance with the policy objective. Figure 1 shows the favorable instrument(s) in controlling regional inflation in Indonesia. 


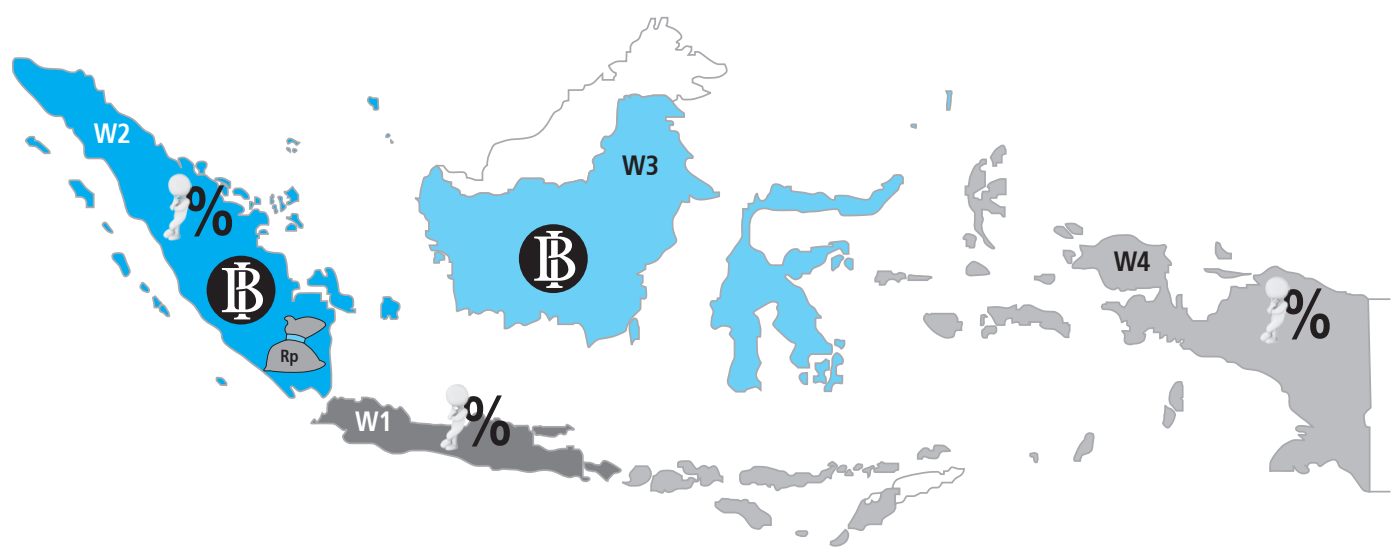

Provincial Money Supply $\quad$ B Bl Rate $\quad \%$ PUAB

Figure 1

Most Favorable Instrument in Controlling Regional Inflation in Indonesia

Each region has their own favorable monetary instrument in controlling inflation. However, in Java-Bali (W1) and Papua-Maluku-Nusa Tenggara (W4), inflation can only be managed using PUAB, while Kalimantan-Sulawesi's (W3) inflation can only be controlled using BI Rate. Combining $\mathrm{BI}$ Rate and PUAB, monetary authority can effectively control inflation in every region in Indonesia. Hence, we conclude that the implementation of interest rate as the monetary instrument in Indonesia is more appropriate than money supply. 


\section{REFERENCES}

Bank Indonesia, (2009), Kajian Ekonomi Regional Provinsi DKI Jakarta Triwulan IV 2009, Bank Indonesia, Jakarta.

Batini, N., and Nelson, E. "The Lag from Monetary Policy Actions to Inflation: Friedman Revisited", International Finance, 2001, 4(3), pp. 381-400.

Brzoza-Brzezina, Michal. "The Relationship Between Real Interest Rates and Inflation". National Bank of Poland Working Papers No. 23, 2002.

Calvo, Guillermo, A. "Staggered Prices in Utility Maximizing Framework", Journal of Monetary Economics, 1983, 12(3), pp. 383-398.

Carneiro, F. G., Divino, J., and Rocha, C. H. "Revisiting the Fisher Hypothesis for Cases Argentina, Brazil and Mexico", Applied Economics Letters, 2002, 9, 95-98.

Chaban, M., and Voss, G. M. "National and Provincial Inflation in Canada: Experiences Under Inflation Targeting". Department of Economics University of Victoria Discussion Paper No. DDP1201, 2012.

Clarida, R., Gali, J., and Gertler, M. "Monetary Policy Rules and Macroeconomic Stability: Evidence and Some Theory", Quarterly Journal of Economics, 2000, 115(1), pp. 147-180.

Fried, J, and Howitt, P. "The Effects of Inflation on Real Interest Rates", The American Economic Review, 1983, 73(5), pp. 968-980.

Gali, J., and Gertler, M. "Inflation Dynamics: A Structural Econometric Analysis", Journal of Monetary Economics, 1999, 44, pp. 195-222.

Garcia, M. G. "The Fisher Effect in a Signal Extraction Framework: The Recent Brazilian Experience", Journal of Development Economics, 1993, 41, pp. 71-93.

Goto, S., and Torous, W. "Evolving Inflation Dynamics, Monetary Policy, and the Fisher Hypothesis". AFA 2014 San Diego Meetings, 2014.

Handa, J., (2009), Monetary Economics, Routledge, London and New York.

Lucas, R. E. "Two Illustrations of the Quantity Theory of Money", The American Economic Review, 1980, 70(5), pp. 1005-1014.

MacCallum, B. T., and Nelson, E. "Money and Inflation: Some Critical Issues". Finance and Economics Discussion Series No. 2010-57, 2010.

Mehrotra, A., Peltonen, T., and Rivera, A. S. "Modeling Inflation in China: A Regional Perspective". European Central Bank Working Paper Series No. 829/November 2007, 2007. 
Mishkin, F. S. "Symposium on the Monetary Transmission Mechanism", Journal of Economic Perspectives, 1995, 9(4), pp. 3-10.

Michell-Innes, H. A. "The Relationship Between Interest Rates and Inflation in South Africa: Revisiting Fisher's Hyphotesis". Master Thesis, Rhodes University, 2006.

Monnet, C., and Weber, W. E. "Money and Interest Rates", Federal Reserve Bank of Minneapolis Quarterly Review, 2001, 25(4), pp. 2-13.

Phylaktis, K., and Blake, D. "The Fisher Hypothesis: Evidence From Three High Inflation Economies", Weltwirtschaftliches Archiv, 1993, 129(3), pp. 591-599.

Ridhwan, M. M., De Groot, H. L., F., Rietveld, P., and Nijkamp, P. "The Regional Impact of Monetary Policy in Indonesia". Tinbergen Institute Discussion Paper No. TI2011-081/3, 2011.

Shrestha, K., Chen, S., and Lee, C. "Are Expected Inflation Rates and Expected Real Rates NegativeLy Correlated? A Long-run Test of The Mundell-Tobin Hyphothesis", The Journal of Financial Research, 2002, 25(3), pp. 305-320.

Taylor, J. B. "The Monetary Transmission Mechanism: An Empirical Framework", Journal of Economic Perspective, 1995, 9(4), pp. 11-26.

Woodford, M., (2003), Interest and Prices: Foundations of a Theory of Monetary Policy, Princeton University Press, 2003. 